\title{
Zaburzenie homeostazy lipidowej w deficycie lizosomalnej lipazy - patomechanizm, diagnostyka i leczenie
}

\section{STRESZCZENIE}

T ipaza lizosomalna katalizuje reakcję hydrolizy estrów cholesterolu i triglicerydów, której produktem są wolne kwasy tłuszczowe i wolny cholesterol, będące kluczowymi mediatorami wewnątrzkomórkowej homeostazy lipidowej. Deficyt LAL jest chorobą monogenową, spowodowaną obecnością patogennych wariantów molekularnych $\mathrm{w}$ genie LIPA, o dziedziczeniu autosomalnym recesywnym. W deficycie LAL dochodzi do kumulacji estrów cholesterolu i trójglicerydów w lizosomach, co wtórnie powoduje zwiększoną syntezę endogennego cholesterolu, apolipoproteiny B oraz lipoprotein o bardzo niskiej gęstości (VLDL). Diagnostyka deficytu kwaśnej lipazy jest łatwa, dzięki dostępnej obecnie metodzie badania aktywności enzymu w suchej kropli krwi. Analiza molekularna jest niezbędna celem weryfikacji diagnozy klinicznej i biochemicznej oraz analizy korelacji genotyp-fenotyp. Sebelipaza alfa jest rekombinowaną ludzką lizosomalną lipazą przeznaczoną do stosowania $\mathrm{w}$ enzymatycznej terapii zastępczej u pacjentów $\mathrm{z}$ niedoborem LAL.

\section{WPROWADZENIE}

Lipaza lizosomalna (ang. lysosomal acid lipase, LAL) zwana jest również kwaśną lipazą, kwaśną esterazą lub hydrolazą estrów cholesterolu. Jest obecna praktycznie we wszystkich komórkach organizmu, z wyjątkiem erytrocytów. Katalizuje reakcję hydrolizy estrów cholesterolu i triglicerydów, której produktem są wolne kwasy tłuszczowe i wolny cholesterol, będące kluczowymi mediatorami wewnątrzkomórkowej homeostazy lipidowej [1-2].

Deficyt LAL jest chorobą monogenową, spowodowaną obecnością patogennych wariantów molekularnych $w$ genie LIPA, o dziedziczeniu autosomalnym recesywnym. W zależności od stopnia niedoboru LAL, wyróżnia się dwa fenotypy choroby:

- chorobę Wolmana (deficyt LAL o wczesnym początku) - ciężką postać, z głębokim niedoborem (lub brakiem) aktywności enzymu,

- chorobę spichrzania estrów cholesterolu (deficyt LAL o późnym początku) postać łagodniejszą, z zachowaną resztkową aktywnością enzymu [2-6].

Pierwszy opis (1956 r.) deficytu LAL o wczesnym początku przedstawiony przez Wolmana dotyczył niemowlęcia z powiększeniem wątroby i śledziony oraz masywnym zwapnieniem nadnerczy [7]. Z kolei, pierwszy opis (1963 r.) deficytu LAL o późnym początku przedstawił Fredrickson i dotyczył dziecka z hiperlipidemią i powiększeniem wątroby [8]. W 1969 roku Patrick i Lake wykazali deficyt aktywności LAL u podłoża choroby opisywanej przez Wolmana i Fredricksona [9].

\section{PATOMECHANIZM}

Cholesterol syntetyzowany jest we wszystkich tkankach (zawierających komórki jądrzaste) z acetylo-CoA. Jest podstawowym składnikiem błon komórkowych oraz prekursorem wszystkich innych steroidów w organizmie (m.in. kortykosteroidy, hormony płciowe, kwasy żółciowe). Ponad połowa cholesterolu organizmu człowieka pochodzi z syntezy (10\% w wątrobie, $10 \% \mathrm{w}$ jelicie), pozostała część jest dostarczana do organizmu z pokarmem. Biosynteza cholesterolu odbywa się w 5 etapach, podczas gdy etap reduktazy HMG-CoA jest głównym momentem ograniczającym dynamikę biosyntezy cholesterolu [10-11].

Cholesterol jest przenoszony w osoczu w postaci zestryfikowanej przez cząsteczki lipoprotein o niskiej gęstości (LDL). Frakcja LDL jest główną frakcją transportującą cholesterol i zawiera około $70 \%$ całkowitego cholesterolu zawartego w surowicy. LDL pełnią swą funkcję poprzez odkładanie wolnego cholesterolu na

\section{dr n. med. Patryk Lipiński,}

\section{prof. dr hab. n. med. Anna Tylki-Szymańska ${ }^{\varpi}$}

Klinika Pediatrii, Żywienia i Chorób Metabolicznych, Instytut „Pomnik - Centrum Zdrowia Dziecka", Warszawa

https://doi.org/10.18388/pb.2021_389

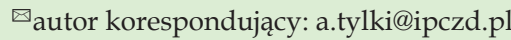

Słowa kluczowe: cholesterol; estry cholesterolu; lipaza lizosomalna; deficyt lipazy lizosomalnej; sucha kropla krwi; enzymatyczna terapia zastępcza 
powierzchni błon komórkowych lub poprzez wiązanie się $\mathrm{z}$ receptorem błonowym, który rozpoznaje zawarta $\mathrm{w}$ nich apoproteinę B-100 (apoB-100). Po związaniu z receptorem LDL są wchłaniane do wnętrza komórki drogą endocytozy, gdzie estry cholesterolu są hydrolizowane, a cholesterol jest następnie dostarczany do aparatu Golgiego celu przechowywania lub ponownego wykorzystania (Ryc. 1) [12].

Transport cholesterolu z lizosomu wymaga obecności i współpracy dwóch białek, zwanych białkami Niemanna-Picka (NP) C1 oraz C2. Białko NPC2, umiejscowione w świetle endosomu, wiąże wolny cholesterol i transportuje go do transbłonowego białka NPC1, które kieruje wolny cholesterol do miejsc docelowych [13-15]. Brak funkcjonalnych białek kodowanych przez odpowiadające im geny (NPC1, NPC2) skutkuje chorobą Niemanna-Picka typu C [16].

Wewnątrzkomórkowy wolny cholesterol oddziałuje z jądrowymi czynnikami transkrypcyjnymi z rodziny SREBP (ang. sterol regulatory element-binding protein), prowadząc do zmniejszenia syntezy cholesterolu endogennego (hamowanie aktywności reduktazy 3-hydroksy-3-metyloglutarylo-koenzymu A, HMG-CoA), zmniejszenia syntezy receptora LDL (hamowanie transkrypcji genu receptora LDL), oraz pobudzenia syntezy estrów cholesterolu (wzrost aktywności acylotransferazy acylocholesterolowej, ACAT) (Ryc. 1) [3,15-16].

W deficycie LAL dochodzi do kumulacji estrów cholesterolu i trójglicerydów w lizosomach [2]. Wynikający z tego niedobór wolnego cholesterolu wewnątrzkomórkowego skutkuje zwiększeniem syntezy endogennego cholesterolu, zwiększeniem ekspresji genu receptora LDL oraz zwiększo- ną produkcją lipoprotein o bardzo niskiej gęstości (VLDL) i w efekcie ich przemian lipoprotein LDL (Ryc. 1) [3-5,17]. Pacjenci z deficytem LAL mają dyslipidemię charakteryzującą się podwyższonym stężeniem cholesterolu całkowitego, cholesterolu frakcji LDL oraz triglicerydów w surowicy, a także prawidłowym lub obniżonym stężeniem cholesterolu frakcji HDL [3-5,17]. Wzrost stężenia cholesterolu całkowitego i trójglicerydów wynika z akumulacji w osoczu lipoprotein bogatych $\mathrm{w}$ apoB. Obniżone stężenie cholesterolu frakcji HDL nie zostało do końca uzasadnione; w badaniach in vitro wykazano zmniejszone tworzeniem dojrzałego HDL [18].

Wątroba jest głównym narządem endocytozy zależnej od receptorów i lizosomalnej degradacji LDL (ponad 70\% LDL jest metabolizowane przez wątrobę), dlatego też deficyt LAL należy do wrodzonych chorób metabolicznych z dominującą ekspresją w wątrobie [19-20]. Powiększenie wątroby, jak również śledziony związane jest z lizosomalnym magazynowaniem estrów cholesterylu i triglicerydów w makrofagach (w przypadku wątroby także w hepatocytach) [21]. Zwapnienia nadnerczy są z kolei związane ze szczególnie aktywną ścieżką endocytozy za pośrednictwem receptorów i lizosomalnej degradacji LDL, które dostarczają prekursorów steroli do steroidogenezy.

Łagodny przebieg kliniczny choroby spichrzania estrów cholesterolu $\mathrm{w}$ porównaniu $\mathrm{z}$ chorobą Wolmana wynika $\mathrm{z}$ faktu zachowanej resztkowej aktywność LAL, która jest wystarczająca do uwolnienia niezbędnej ilości wolnego cholesterolu z lizosomów i w efekcie hamowania aktywności aktywności reduktazy HMG-CoA oraz zmniejszenia syntezy receptora LDL [3].
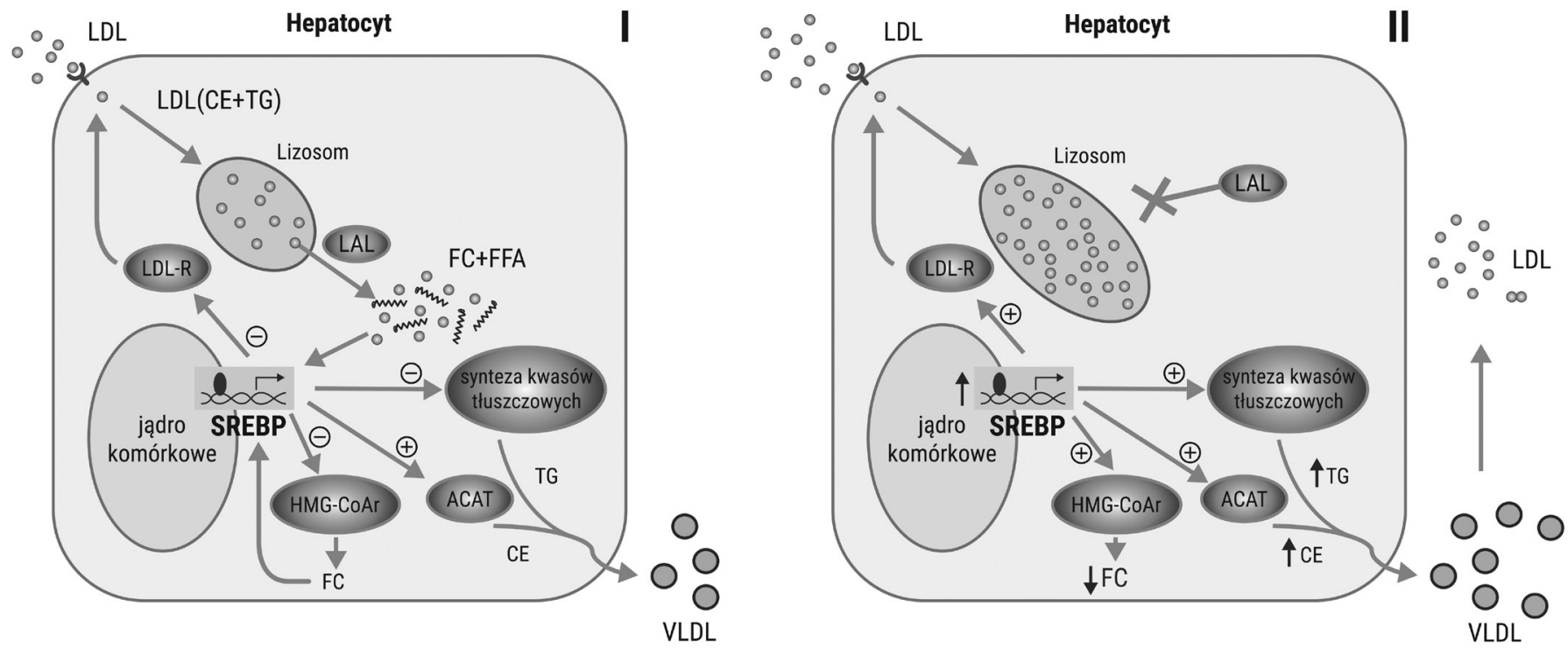

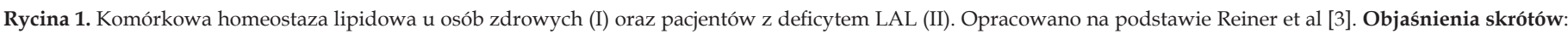

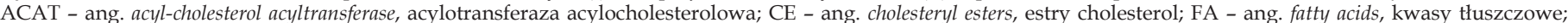

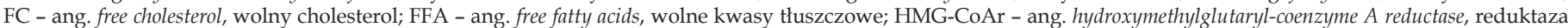

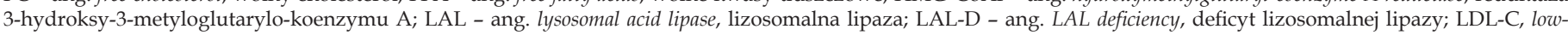

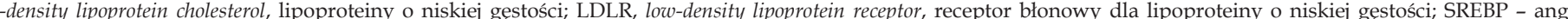

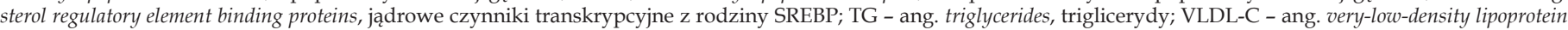
cholesterol, lipoproteiny o bardzo niskiej gęstości. 


\section{OBJAWY KLINICZNE I BIOCHEMICZNE}

Deficyt LAL o wczesnym początku (choroba Wolmana) charakteryzuje się ostrym początkiem w pierwszych tygodniach życia. Cechami charakterystycznymi są wyraźne powiększenie wątroby i śledziony (spowodowane kumulacją estrów cholesterolu i triglicerydów), wymioty i biegunka (efekt zaburzeń wchłaniania w wyniku nagromadzenie lipidów w błonie śluzowej jelit), wzdęcie brzucha, zahamowanie przyrostu masy ciała [3,6,22-24].

Powiększenie oraz zwapnienie nadnerczy stanowi objaw patognomoniczny. Niedokrwistość zwykle pojawia się ok. 6. tygodnia życia i nasila się w miarę postępu choroby. Inne odchylenia $\mathrm{w}$ badaniach laboratoryjnych obejmują: podwyższoną aktywność aminotransferaz, cholestazę, małopłytkowość, zaburzenia krzepnięcia. Choroba charakteryzuje się szybko postępującym wyniszczeniem, prowadzącym do zgonu w okresie niemowlęcym (zwykle przed ukończeniem 6. miesiąca życia) [3,6,22-24].

Deficyt LAL o późnym początku zwany jest także chorobą spichrzania estrów cholesterolu (ang. cholesteryl ester storage disease, CESD) charakteryzuje się łagodnym początkiem w 1. lub 2. dekadzie życia lub nawet później. Najbardziej charakterystyczne jest powiększenie wątroby, które może utrzymywać się przez wiele lat przed rozpoznaniem choroby. Powiększenie śledziony jest obserwowane $u 1 / 3$ pacjentów. Ponadto, charakterystyczna jest hiperlipidemia, definiowana jako podwyższone stężenia cholesterolu całkowitego, triglicerydów i cholesterolu frakcji LDL, a także prawidłowe/obniżone stężenie cholesterolu frakcji HDL. U części (30-50\%) pacjentów obserwuje się łagodne/ umiarkowane podwyższenie aktywności aminotransferaz w surowicy krwi. Uszkodzenie wątroby może postępować z czasem, prowadząc do włóknienia wątroby. W tej postaci niezwykle rzadko spotykane jest powiększenie i zwapnienie nadnerczy [2-6,24-25].

Pacjenci z deficytem LAL o późnym początku są narażeni na przyspieszony rozwój miażdżycy z uwagi na infiltrację śródbłonka naczyniowego lipidami [25-26].

CESD może mieć przebieg postępujący, co wykazano na przykładzie polskiej pacjentki, u której w ciągu 4 lat od momentu rozpoznania (w wieku 3 lat) obserwowano masywną kumulację makrofagów skutkującą powiększeniem węzłów chłonnych jamy brzusznej, powiększeniem wątroby i śledziony oraz tworzeniem guzków podskórnych [21]. Badanie histopatologiczne węzłów chłonnych i guzków podskórnych wykazało, że są nacieczone przez makrofagi obładowane lipidami (Ryc. 2).

\section{DIAGNOSTYKA}

Na podstawie historii naturalnej przebiegu choroby spichrzania estrów cholesterolu w grupie 19 polskich pacjentów oraz przeglądu piśmiennictwa zaproponowany został algorytm diagnostyczny [4]. W przypadku współistnienia powiększenia wątroby czy powiększenia wątroby i śledziony oraz podwyższonej aktywności aminotransferaz w suro-

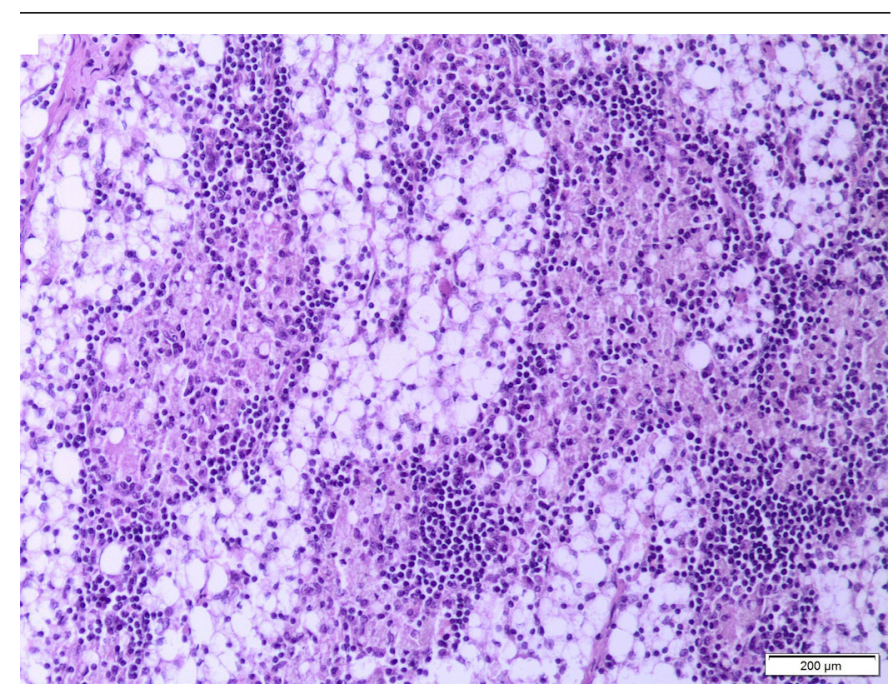

Rycina 2. Makrofagi obładowane lipidami, barwienie H\&E.

wicy i dyslipidemii, wskazana jest diagnostyka w kierunku deficytu LAL [4].

Diagnostyka deficytu kwaśnej lipazy jest łatwa, dzięki dostępnej obecnie metodzie badania aktywności enzymu $\mathrm{w}$ suchej kropli krwi (ang. dried blood spot, DBS) opracowanej przez Hamiltona [27]. W przypadkach wątpliwych ocena aktywności LAL w leukocytach lub fibroblastach skóry jest wskazana [27].

Analiza molekularna jest niezbędna celem weryfikacji diagnozy klinicznej i biochemicznej oraz analizy korelacji genotyp-fenotyp. Mutacja c.894G>A, p.(delS275_Q298) stanowi najczęstszy wariant patogenny raportowany wśród pacjentów z CESD populacji rasy kaukaskiej [28]. W polskiej populacji wykazano, że obecność mutacji c.894G>A na co najmniej jednym allelu genu LIPA, łagodzi fenotyp kliniczny choroby spichrzania estrów cholesterolu [4]. W grupie pacjentów z Rosji i Ukrainy wykazano ponadto, że homozygoty mogą mieć przebieg kliniczny niemal bezobjawowy.

Deficyt LAL można również potwierdzić poprzez wykazanie spichrzania estrów cholesterolu i triglicerydów za pomocą chromatografii cienkowarstwowej lipidów wątroby [29]. Wątroba w CESD ma charakterystyczny pomarańczowy lub kremowo-żółty kolor, a także miękką konsystencję. W obrazie histologicznym bioptatów wątroby dominuje stłuszczenie mikropęcherzykowe [4-5]. Obecność igieł cholesterolowych w bioptacie wątroby mocno sugeruje deficyt LAL w mikroskopii elektronowej [4,29].

\section{LECZENIE}

Historycznie, leczenie deficytu LAL polegało na leczeniu hipercholesterolemii, stosując interwencje dietetyczne (dieta ubogocholesterolowa) i leki obniżające poziom cholesterolu, zwłaszcza statyny (inhibitory reduktazy HMG-CoA). Rola statyn w leczeniu pacjentów z deficytem niedoborem LAL jest niepotwierdzona, jednakże biorąc pod uwagę patomechanizm choroby stosowanie statyn wydaje się nie mieć większego wpływu na zaburzenia lipidowe w deficycie LAL [29-31]. 
Enzymatyczna terapia zastępcza sebelipazą alfa została zatwierdzona w Stanach Zjednoczonych i Unii Europejskiej w 2015 roku. Sebelipaza alfa (produkt KANUMA) jest rekombinowaną ludzką lizosomalną lipazą przeznaczoną do stosowania w enzymatycznej terapii zastępczej u pacjentów z niedoborem LAL [29,32]. W badaniach klinicznych $\mathrm{w}$ grupie pacjentów z deficytem LAL o późnym początku wykazano wpływ na normalizację objętości wątroby i śledziony, normalizację aktywności aminotransferazy alaninowej, statystycznie istotną poprawę parametrów gospodarki lipidowej, a w grupie pacjentów z deficytem LAL o wczesnym początku zwiększenie przeżywalności [29,3233]. Transplantacja hematopoetycznych komórek macierzystych u pacjentów z deficytem LAL o wczesnym początku jest obarczona wysoką śmiertelnością, głównie z uwagi na niepomyślny naturalny przebieg choroby [34].

\section{PIŚMIENNICTWO}

1. Gomaraschi M, Bonacina F, Norata GD (2019) Lysosomal Acid Lipase: From Cellular Lipid Handler to Immunometabolic Target. Trends Pharmacol Sci 40: 104-115

2. Tylki-Szymańska A, Jurecka A (2014) Lysosomal acid lipase deficiency: wolman disease and cholesteryl ester storage disease. Pril (Makedon Akad Nauk Umet Odd Med Nauki) 35: 99-106

3. Reiner Ž, Guardamagna O, Nair D, Soran H, Hovingh K, Bertolini S, Jones S, Ćorić M, Calandra S, Hamilton J, Eagleton T, Ros E (2014) Lysosomal acid lipase deficiency - an under-recognized cause of dyslipidaemia and liver dysfunction. Atherosclerosis 235: 21-30

4. Lipiński P, Ługowska A, Zakharova EY, Socha P, Tylki-Szymańska A (2018) Diagnostic Algorithm for Cholesteryl Ester Storage Disease: Clinical Presentation in 19 Polish Patients. J Pediatr Gastroenterol Nutr 67: 452-457

5. Bernstein DL, Hülkova H, Bialer MG, Desnick RJ (2013) Cholesteryl ester storage disease: review of the findings in 135 reported patients with an underdiagnosed disease. J Hepatol 58: 1230-1243

6. Pericleous M, Kelly C, Wang T, Livingstone C, Ala A (2017) Wolman's disease and cholesteryl ester storage disorder: the phenotypic spectrum of lysosomal acid lipase deficiency. Lancet Gastroenterol Hepatol 2: 670-679

7. Abramov A, Schorr S, Wolman M (1956) Generalized xanthomatosis with calcified adrenals. AMA J Dis Child 91: 282

8. Fredrickson DS (1963) Newly recognized disorders of cholesterol metabolism. Ann Intern Med 58: 718

9. Patrick AD, Lake BD (1969) Deficiency of an acid lipase in Wolman's disease. Nature 222: 1067-1068

10. Cerqueira NM, Oliveira EF, Gesto DS, Santos-Martins D, Moreira C, Moorthy HN, Ramos MJ, Fernandes PA (2016) Cholesterol Biosynthesis: A Mechanistic Overview. Biochemistry 55: 5483-5506

11. Luo J, Yang H, Song BL (2020) Mechanisms and regulation of cholesterol homeostasis. Nat Rev Mol Cell Biol 21: 225-245

12. Ference BA, Kastelein JJP, Catapano AL (2020) Lipids and Lipoproteins in 2020. JAMA 324: 595-596

13. Vanier MT, Millat G (2004) Structure and function of the NPC2 protein. Biochim Biophys Acta 1685: 14-21

14. Pfeffer SR (2019) NPC intracellular cholesterol transporter 1 (NPC1)-mediated cholesterol export from lysosomes. J Biol Chem 294: 1706-1709

15. Ramirez CM, Liu B, Aqul A, Taylor AM, Repa JJ, Turley SD, Dietschy JM (2011) Quantitative role of LAL, NPC2, and NPC1 in lysosomal cholesterol processing defined by genetic and pharmacological manipulations. J Lipid Res 52: 688-698

16. Vanier MT (2010) Niemann-Pick disease type C. Orphanet J Rare Dis 5: 16
13. Guardamagna O, Guaraldi F (2017) Lysosomal Acid Lipase Deficiency: Could Dyslipidemia Drive the Diagnosis? Curr Pediatr Rev 13:23242

14. Li F, Zhang H (2019) Lysosomal Acid Lipase in Lipid Metabolism and Beyond. Arterioscler Thromb Vasc Biol 39: 850-856

15. Jeon TI, Osborne TF (2012) SREBPs: metabolic integrators in physiology and metabolism. Trends Endocrinol Metab 23: 65-72

16. Horton JD, Goldstein JL, Brown MS (2002) SREBPs: activators of the complete program of cholesterol and fatty acid synthesis in the liver. J Clin Invest 109: 1125-1131

17. Zhang H (2018) Lysosomal acid lipase and lipid metabolism: new mechanisms, new questions, and new therapies. Curr Opin Lipidol 29: 218-223

18. Bowden KL, Bilbey NJ, Bilawchuk LM, Boadu E, Sidhu R, Ory DS, Du H, Chan T, Francis GA (2011) Lysosomal acid lipase deficiency impairs regulation of $\mathrm{ABCA1}$ gene and formation of high density lipoproteins in cholesteryl ester storage disease. J Biol Chem 286: 30624-30635

19. Lipiński P, Szymańska E, Tylki-Szymańska A (2018) Choroby metaboliczne wątroby przebiegające z jej powiększeniem. Pediatr Pol 93: 165-79

20. Lipiński P, Jankowska I, Szymańska E, Rokicki D, Tylki-Szymańska A (2018) Hepato- i splenomegalia w wybranych chorobach metabolicznych - diagnostyka i różnicowanie. Pediatr Pol 93: 74-9

21. Lipiński P, Cielecka-Kuszyk J, Bożkiewicz-Kasperczyk A, Perkowska B, Jurkiewicz E, Tylki-Szymańska A (2020) Progressive macrophage accumulation in lysosomal acid lipase deficiency. Mol Genet Metab Rep 23: 100594

22. Cohen JL, Burfield J, Valdez-Gonzalez K, Samuels A, Stefanatos AK, Yudkoff M, Pedro H, Ficicioglu C (2019) Early diagnosis of infantile-onset lysosomal acid lipase deficiency in the advent of available enzyme replacement therapy. Orphanet J Rare Dis 14: 198

23. Santos Silva E, Klaudel-Dreszler M, Bakuła A, Oliva T, Sousa T, Fernandes PC, Tylki-Szymańska A, Kamenets E, Martins E, Socha P (2018) Early onset lysosomal acid lipase deficiency presenting as secondary hemophagocytic lymphohistiocytosis: Two infants treated with sebelipase alfa. Clin Res Hepatol Gastroenterol 42: 77-82

24. Kohli R, Ratziu V, Fiel MI, Waldmann E, Wilson DP, Balwani M (2020) Initial assessment and ongoing monitoring of lysosomal acid lipase deficiency in children and adults: Consensus recommendations from an international collaborative working group. Mol Genet Metab 129: 59-66

25. Poinsot P, Collardeau Frachon S, Restier L, Sérusclat A, Di Filippo M, Charrière S, Moulin P, Lachaux A, Peretti N (2017) Childhood/ adult-onset lysosomal acid lipase deficiency: A serious metabolic and vascular phenotype beyond liver disease-four new pediatric cases. J Clin Lipidol 11: 167-77

26. Reynolds T (2013) Cholesteryl ester storage disease: a rare and possibly treatable cause of premature vascular disease and cirrhosis. J Clin Pathol 66: 918-923

27. Hamilton J, Jones I, Srivastava R, Galloway P (2012) A new method for the measurement of lysosomal acid lipase in dried blood spots using the inhibitor Lalistat 2. Clin Chim Acta 413: 1207-1210

28. Scott SA, Liu B, Nazarenko I, Martis S, Kozlitina J, Yang Y, Ramirez C, Kasai Y, Hyatt T, Peter I, Desnick RJ (2013) Frequency of the cholesteryl ester storage disease common LIPA E8SJM mutation (c.894G>A) in various racial and ethnic groups. Hepatology 58: 958-965

29. Tylki-Szymańska A, Rujner J, Lugowska A, Sawnor-Korszyńska D, Woźniewicz B, Czarnowska E (1997) Clinical, biochemical and histological analysis of seven patients with cholesteryl ester storage disease. Acta Paediatr Jpn 39: 643-646

29. Pastores GM, Hughes DA (2020) Lysosomal Acid Lipase Deficiency: Therapeutic Options. Drug Des Devel Ther 14: 591-601

30. Di Rocco M, Pisciotta L, Madeo A, Bertamino M, Bertolini S (2018) Long term substrate reduction therapy with ezetimibe alone or associated with statins in three adult patients with lysosomal acid lipase deficiency. Orphanet J Rare Dis 13: 24 
31. Fouchier SW, Defesche JC (2013) Lysosomal acid lipase A and the hypercholesterolaemic phenotype. Curr Opin Lipidol 24: 332-338

32. Frampton JE (2016) Sebelipase Alfa: A Review in Lysosomal Acid Lipase Deficiency. Am J Cardiovasc Drugs 16: 461-468

33. Malinová V, Balwani M, Sharma R, Arnoux JB, Kane J, Whitley CB, Marulkar S, Abel F (2020) Sebelipase alfa for lysosomal acid lipase de- ficiency: 5-year treatment experience from a phase 2 open-label extension study. Liver Int 40: 2203-2214

34. Jones SA, Valayannopoulos V, Schneider E, Eckert S, Banikazemi M, Bialer M, Cederbaum S, Chan A, Dhawan A, Di Rocco M, Domm J, Enns GM, Finegold D, Gargus JJ, Guardamagna O, Hendriksz C, Mahmoud IG, Raiman J, Selim LA, Whitley CB, Zaki O, Quinn AG (2016) Rapid progression and mortality of lysosomal acid lipase deficiency presenting in infants. Genet Med 18: 452-458

\title{
Disturbance of lipid homeostasis in lysosomal lipase deficiency - pathomechanism, diagnosis and treatment
}

\section{Patryk Lipiński, Anna Tylki-Szymańska ${ }^{\square}$}

Department of Paediatrics, Nutrition and Metabolic Diseases, The Children's Memorial Health Institute, 04-730 Warsaw

$\llbracket$ Corresponding author: a.tylki@ipczd.pl

Key words: cholesterol; lysosomal acid lipase; lysosomal acid lipase deficiency; dried blood spot; enzyme replacement therapy.

\begin{abstract}
Lysosomal acid lipase (LAL) plays a key role in lipid metabolism through the hydrolysis of cholesteryl esters and triglycerides in lysosomes. LAL deficiency is a rare autosomal recessive lysosomal storage disease caused by deleterious mutations in the LIPA gene. In the case of LAL deficiency, cholesteryl esters and triglycerides accumulate within the lysosomes. The up-regulation of endogenous cholesterol production, increased synthesis of apolipoprotein B and increased production of very-low-density lipoprotein cholesterol is observed. The diagnosis is easy due to the currently available method of testing the enzyme activity in a dry blood spot. Molecular analysis is necessary to verify the clinical and biochemical diagnosis and to analyze the genotype-phenotype correlation. Sebelipase alfa is a recombinant human lysosomal lipase intended for use in enzyme replacement therapy in patients with LAL deficiency.
\end{abstract}

\section{Deficyt lizosomalnej (kwaśnej) lipazy (LAL)}

głęboki niedobór (lub brak) aktywności enzymu

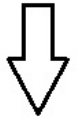

\section{Deficyt LAL o wczesnym początku (choroba Wolmana)}

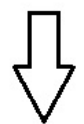

- $\quad$ ostry początek w pierwszych tygodniach życia,

- wyraźne powiększenie wątroby i śledziony (spowodowane kumulacją estrów cholesterolu i triglicerydów),

- wymioty i biegunka (efekt zaburzeń wchłaniania w wyniku nagromadzenia lipidów w błonie śluzowej jelit),

- zahamowanie przyrostu masy ciała,

- $\quad$ powiększenie oraz zwapnienie nadnerczy stanowi objaw patognomoniczny,

- podwyższona aktywność aminotransferaz, niedokrwistość, małopłytkowość, zaburzenia krzepnięcia,

- $\quad$ szybko postępujące wyniszczenie,

- $\quad$ zgon w okresie niemowlęcym

(zwykle przed ukończeniem 6. miesiąca życia) zachowana resztkowa aktywność enzymu
Deficyt LAL o późnym początku (choroba spichrzania estrów cholesterolu)
- $\quad$ łagodny początek w 1. lub 2. dekadzie życia lub nawet później,

- najbardziej charakterystyczne jest powiększenie wątroby, które może utrzymywać się przez wiele lat przed rozpoznaniem choroby,

- $\quad$ powiększenie śledziony jest obserwowane u $1 / 3$ pacjentów,

- charakterystyczna jest hiperlipidemia, definiowana jako podwyższone stężenia cholesterolu całkowitego, triglicerydów i cholesterolu frakcji LDL, a także prawidłowe/obniżone stężenie cholesterolu frakcji HDL,

- $\quad$ uszkodzenie wątroby w deficycie LAL może postępować z czasem, prowadząc do włóknienia wątroby,

- możliwy przyspieszony rozwój miażdżycy z uwagi na infiltrację śródbłonka naczyniowego lipidami 